\title{
$\mathrm{COSCi}_{\text {ech }}$ Jurnal Computer Science and Information Technology (CoSciTech)
}

\section{Perancangan User Interface Website E-Commerce Pada Usaha Kuliner Menggunakan User Centered Design}

\author{
Ari Andriyas Puji', Vivi Engraini \\ Email: ${ }^{2}$ andriyasari@umri.ac.id, ${ }^{2}$ viviengraini29@ gmail.com \\ ${ }^{1}$ Teknik Industri, Fakultas Teknik, Universitas Muhammadiyah Riau \\ ${ }^{2}$ Teknik Industri, Fakultas Teknik, Universitas Muhammadiyah Riau
}

Diterima: 10 Oktober 2020 | Direvisi: - | Disetujui: 13 Juni 2021

(C2021 Program Studi Teknik Informatika Fakultas Ilmu Komputer,

Universitas Muhammadiyah Riau, Indonesia

\begin{abstract}
Abstrak
Internet telah digunakan oleh banyak orang dari berbagai kalangan untuk mengakses informasi.Umumnya informasi-informasi tersebut disajikan pada website yang dapat dikunjungi oleh pengguna internet kapanpun dan di manapun.Dewasa ini banyak orang yang mengunjungi website e-commerce untuk berbelanja atau mencari informasi mengenai suatu produk.Dengan demikian, dapat disimpulkan bahwa memiliki website e-commerce dapat membantu pelaku usaha untuk memperluas pangsa pasarnya dalam rangka meningkatan penjualan.Penelitian ini bertujuan untuk merancang User Interface (UI) untuk website ecommerce pada usaha kuliner dengan memperhatikan aspek visual dan kemudahan dalam penggunaan (user friendly) sehingga dapat menarik minat pengunjung untuk melakukan pembelian. Adapun perancangan User Interface pada penelitian ini dilakukan menggunakan pendekatan User Centered Design (UCD) dengan 4 tahap penyelesaian yang terdiri dari analisis kebutuhan, perancangan, evaluasi dan implementasi. Berdasarkan hasil penelitian dapat disimpulkan bahwa penerapan User Centered Design (UCD) pada perancangan User Interface dapat memberikan hasil yang lebih baik dengan menitikberatkan pada kebutuhan pengguna sehingga memungkinkan User Interface yang dihasilkan tidak hanya mudah untuk digunakan (user friendly) tetapi juga dapat menarik minat pengunjung untuk melakukan pembelian.
\end{abstract}

Kata kunci: Website, E-Commerce, User Interface, User Centered Design

\section{User Interface Design For E-Commerce Websites In Culinary Business}

\begin{abstract}
Te Internet has been used by many people from various background to accsess information. Generally, the information is presented on a website that can be visited by internet users anytime and anywhere. Nowadays many people visit e-commerce websites to shop and find information about a product. Therefore, having a website can help business actors to expand their market share to increase sales. This research aims to design an user interface (UI) for an e-commerce website in a culinary business by paying attention to visual aspect and ease of use in order to attract visitors to make purchases. The User Interface design in this research was carried out using the User Centered Design (UCD) approach which consist of 4 steps of completion. The stpes are needs analysis, design and evaluation. Based on the results of this reaserch, it is known that the application of User Centered Design (UCD) in User Interface design can provide better results by focusing on user needs so that the User Interface is not only easy to use but also to attract visitors to make purchases.
\end{abstract}

Keywords: Website, E-Commerce, User Interface, User Centered Design

\section{Pendahuluan}

Internet telah digunakan oleh banyak orang dari berbagai kalangan untuk mengakses informasi.Umumnya informasiinformasi tersebut disajikan pada website yang dapat dikunjungi oleh pengguna internet kapanpun dan di manapun.Dewasa ini banyak orang yang mengunjungi website e-commerceuntuk berbelanja dan mencari informasi mengenai suatu produk.Dengan

doi: https://doi.org/10.37859/coscitech.v2i1.2196 
adanya wadah berupa website tersebut, pembeli dan penjual dapat berinteraksi tanpa harus bertemu secara fisik sehingga memungkinkan aktivitas promosi, penjualan, pemesanan dan transaksi dapat dilakukan kapan saja dan di mana saja.Dengan demikian, dapat disimpulkan bahwa memiliki website e-commerce dapat membantu pelaku usaha untuk memperluas pangsa pasarnya dalam rangka meningkatan penjualan.

Rumah Makan Sarang Kepiting merupakan salah satu usaha kuliner yang menyajikan menu olahan seafood di Pekanbaru.Selama ini sistem penjualan di Rumah Makan Sarang Kepiting masih dilakukan secara konvensional di mana pemesanan, pembelian dan transaksi hanya dapat dilakukan oleh pelanggan dengan datang langsung ke outlet. Sistem ini tentu kurang efektif untuk memperluas pangsa pasar mengingat kini telah banyak usaha kuliner serupa yang memberikan layanan delivery order atau layanan pesan antar. Dengan adanya layanan pesan antar tersebut tentunya akan menjadi pertimbangan yang dapat mempengaruhi preferensi konsumen dalam memilih tempat makan terutama untuk di masa pandemi seperti ini di mana masyarakat harus membatasi interaksi fisik dan menghindari keramaian. Selain itu, pelanggan juga sulit untuk mengakses informasi mengenai varian menu dan harga terbaru karena tidak adanya informasi yang dapat diakses melalui internet.Oleh karena itu, perlu dilakukan inovasi untuk memperluas pangsa pasar usaha kuliner Sarang Kepiting dengan membuat sistem $e$ commerce berbasis web.

Dalam membangun sistem berbasis web diperlukan user interface dari sistem itersebut. User Interface (UI) adalah saat di mana sistem dan pengguna dapat saling berinteraksi satu dengan lainnya melalui perintah seperti halnya menggunakan konten dan memasukkan data [1]. Menurut [2], User Interface atau tampilan antarmuka pengguna merupakan bagian yang penting dalam sebuah sistem atau aplikasi karena User Interfaceberinteraksi langsung dengan pengguna.Karena berhubungan langsung dengan pengguna, maka desain User Interface sangat perlu diperhatikan dalam pembuatan sebuah sisteme-commerce. Desain User Interface yang menarik dan mudah digunakan akan dapat mempengaruhi minat pengunjung untuk melakukan pembelian. Sebaliknya, desain User Interface yang buruk akan membuat pengunjung tidak betah berlama-lama mengunjungi website tersebut atau bahkan mengurungkan niat untuk melakukan pembelian.

Penelitian ini bertujuan untuk merancang User Interface untuk website e-commerce pada usaha kuliner Rumah Makan Sarang Kepiting dengan memperhatikan aspek visual dan kemudahan dalam penggunaan (user friendly) sehingga dapat menarik minat pengunjung untuk melakukan pembelian. Adapun perancangan UI pada penelitian ini dilakukan dengan pendekatan User Centered Design (UCD). Menurut [3], UCD merupakan salah satu metode pendekatan dengan konsep pengguna yang dioptimalkan untuk end-user serta ditekankan pada bagaimana kebutuhan atau keinginan pada setiap end-user, dan dirancang sesuai behavior end-user agar pengguna tidak memaksa untuk mengubah perilakunya saat menggunakan produk yang akan dibangun.

\section{Metode Penelitian}

Penelitian ini dilakukan pada usaha kuliner Rumah Sarang Kepiting yang berlokasi di Jalan DR. Soetomo No. 29 Pekanbaru.Permasalahan pada penelitian ini adalah sistem penjualan yang masih dilakukan secara konvensional sehingga perlu dilakukan inovasi dengan membuat website e-commerce untuk memperluas pangsa pasar.Dalam merancang sebuah website, hal yang tidak kalah penting untuk diperhatikan adalah desain User Interface dari website tersebut.Salah satu pendekatan yang dapat digunakan untuk merancang User Interface adalah User Centered Design (UCD). Adapun langkah-langkah yang dilakukan untuk merancang User Interface berdasarkan pendekatan User Centered Design pada penelitian ini dapat dilihat pada Gambar 1.

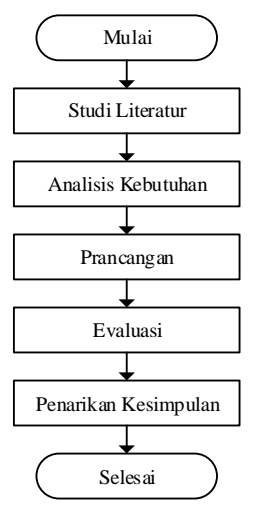

Gambar 1. Metodologi Penelitian

\subsection{Studi Literatur}

Studi literatur dilakukan dengan membaca referensi-referensi yang berhubungan dengan website, e-commerce, perancangan User Interface, User Centered Design dan topik-topik lainnya yang berkaitan dengan permasalahan yang diangkat pada penelitian ini untuk selanjutnya dijadikan sebagai acuan dalam menyelesaikan permasalahan tersebut.

\subsection{Analisis Kebutuhan}

Analisis kebutuhan dilakukan dengan pendekatan User Centered Design. Pada tahap ini dilakukan pengumpulan data melaluibrainstorming dan diskusi dengan owner, pekerja dan pengunjung Sarang Kepiting untuk mengetahui gambaran awal 
dari User Interface yang akan dirancang. Adapun tahapan yang dilakukan dalam analisis kebutuhan menggunakan User Centered Design pada penelitian ini diantaranya adalah memahami dan menentukan konteks pengguna serta melakukan pengumpulan data terkaitapa saja yang menjadi kebutuhan pengguna dan organisasi terhadapUser Interface yang akan dirancang. Hasil dari analisis ini akan dijadikan sebagai acuan dan gambaran untuk membuat rancangan User Interface.

\subsection{Perancangan}

Tahap ini bertujuan untuk membuat sebuah prototype desain User Unterface sistem penjualan berbasis web. Menurut [4], prototype adalah versi awal dari sistem perangkat lunak yang digunakan untuk mendemonstrasikan konsep-konsep percobaan rancangan dan menunjukkan lebih banyak masalah dan solusi yang memungkinkan. Perancangan dilakukan dengan menerapkan 8 aturan emas yang terdiri dari [5]: Consistency; Universal Usability; Feedback; Dialog; Prevent Error; Permit Easy Reversal of Actions; Support Internal Locus of Control; dan Reduce Short-Term Memory Load. Adapun alat yang digunakan untuk membuat rancangan User Interface pada penelitian ini adalah software GUI Design Studio.

\subsection{Evaluasi}

Setelah membuat rancangan User Interface maka tahap selanjutnya adalah mengevaluasi hasil rancangan. Apabila ternyata hasil rancangan masih belum sesuai dengan kebutuhan dan ekspektasi pengguna, maka akan dilakukan perbaikan sesuai dengan hasil evaluasi tersebut. Perbaikan dapat terjadi secara berulang-ulang hingga didapatkan hasil rancangan terbaik yang sesuai dengan kebutuhan dan ekspektasi pengguna.

\subsection{Implementasi}

Pada tahap ini dilakukan perbaikan pada hasil rancangan yang masih belum sesuai dengan kebutuhan dan ekspektasi pengguna dengan mengimplementasikan hasil evaluasi dari pengguna.Perbaikan dapat terjadi secara berulang-ulang hingga didapatkan hasil rancangan terbaik yang sesuai dengan kebutuhan dan ekspektasi pengguna.

\subsection{Penarikan Kesimpulan}

Pada tahap ini dilakukan penarikan kesimpulan dari hasil penelitian yang telah dilakukan.Adapun kesimpulan yang dihasilkan harus dapat menjawab tujuan penelitian yang telah ditetapkan.

\section{HaSil dan Pembahasan}

Dengan menggunakan pendekatan User Centered Design, perancangan User Interface untuk website e-commerce ini akan disesuaikan dengan kebutuhan dan pengalaman pengguna saat berbelanja secara konvesional. Selain itu perancangan ini juga dilakukan dengan memperhatikan 8 aturan emas dalam merancang User Interface yang akan membantu memberikan tampilan yang sangat user friendly. Berikut ini adalah hasil rancangan User Interface untuk website e-commercepada usaha kulinerSarang Kepiting dengan menggunakan pendekatan User Centered Design.

\subsection{Tampilan Halaman Home}

Pada saat mengunjungi website e-commerce Sarang Kepiting, halaman home adalah halaman pertama yang akan ditampilkan kepada pengguna. Pada halaman home ini pengguna dapat melihat pilihan menu-menu favorit yang telah banyak dipesan oleh pelanggan, menu baru dan berbagai promo terbaru. Warna merah dan oranye mendominasi tampilan rancangan User Interface ini karena dinilai dapat membangkitkan selera makan dan membuat lapar mata. Adapun tampilan halaman home dapat dilihat pada Gambar 2.

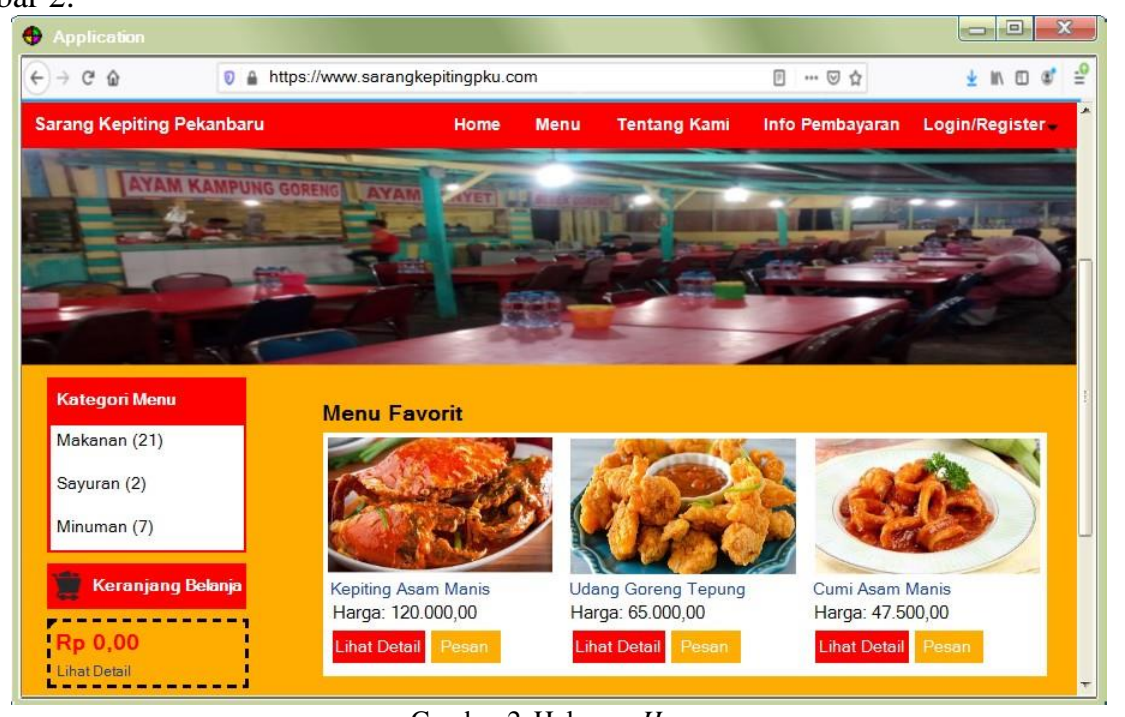

Gambar 2. Halaman Home 


\subsection{Tampilan HalamanLogin dan Register}

Untuk melakukan transaksi, pengguna terlebih dahulu harus memiliki akun dan login ke akun tersebut.Apabila pengguna belum memiliki akun maka pengguna dapat melakukan registrasi. Adapun menu login atau registerini dapat ditemukan dengan meng-klik menu Login/Register yang terletak pada header seperti yang dapat dilihat pada Gambar 3.

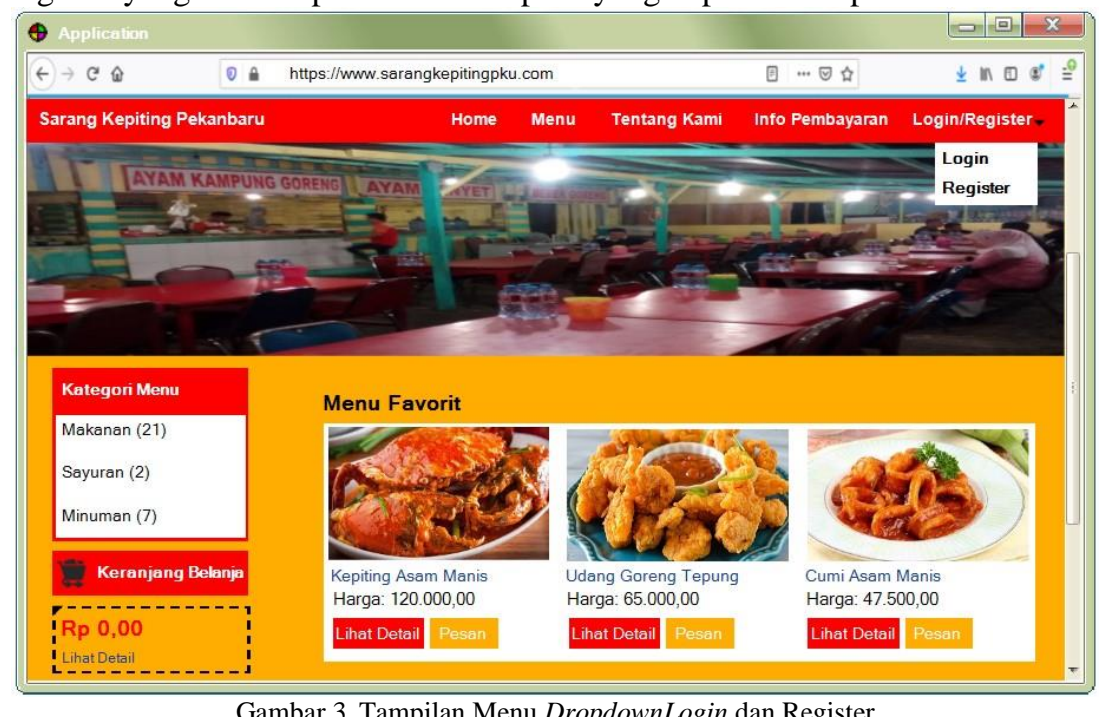

Selanjutnya apabila pengguna meng-klik tombol register maka sistem akan menampilkan halaman registerberupa form yang berisi daftar pertanyaan yang wajib diisi oleh pengguna jika ingin melakukan registrasi. Namun apabila pengguna mengklik tombol login, maka sistem akan menampilkan halaman login dan untuk dapat login pengguna wajib memasukkan alamat email dan password yang telah didaftarkan pada saat melakukan registrasi. Adapun tampilan halaman login dan registerdapat dilihat pada Gambar 4 dan Gambar 5.
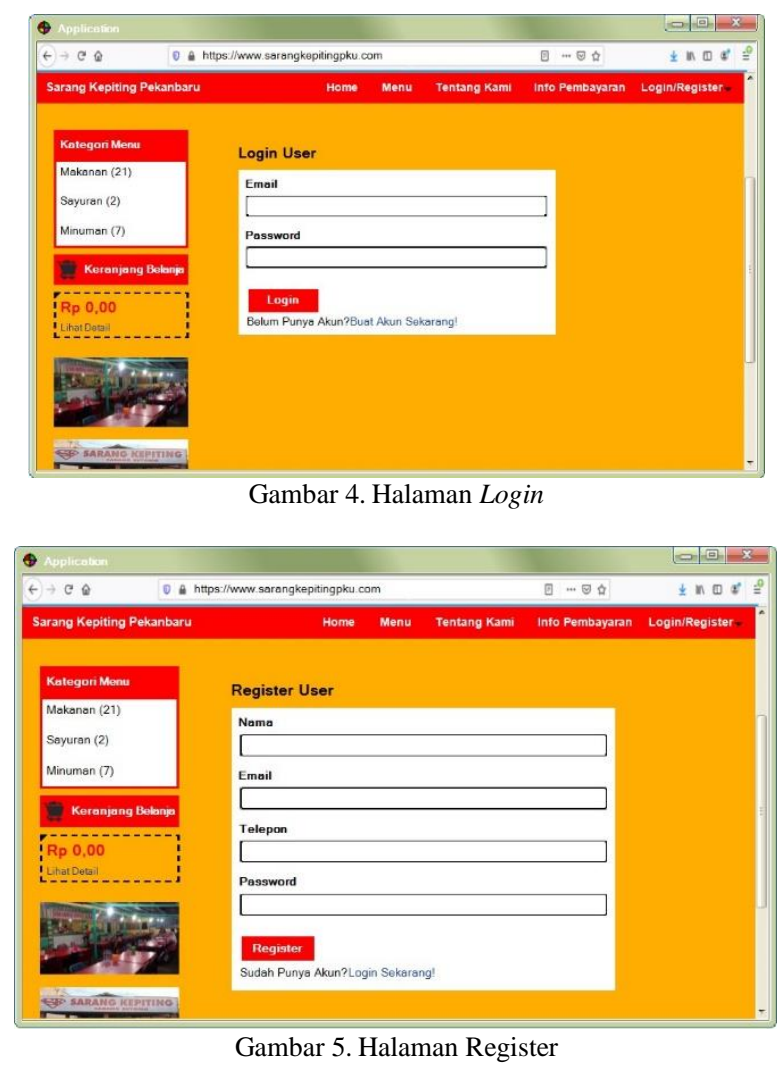

\subsection{Tampilan Halaman Menu}

Halaman menu berfungsi menampilkan menu-menu yang tersedia di Rumah Makan Sarang Kepiting.Menu dapat ditampilkan secara keseluruhan dan dapat ditampilkan berdasarkan kategorinya.Untuk menampilkan menu berdasarkan kategori, pengguna dapat meng-klik salah satu pilihan kategori pada kategori menu yang berada di sebelah kiri atas halaman. Selain itu, 
untuk mempersingkat waktu dan mempermudah pengguna dalam mencari menu pilihannya, pada halaman ini pengguna juga dapat melakukan pencarian menu dengan memasukkan nama menu pada kolom pencarian. Adapun tampilan halaman menu dapat dilihat pada Gambar 6.
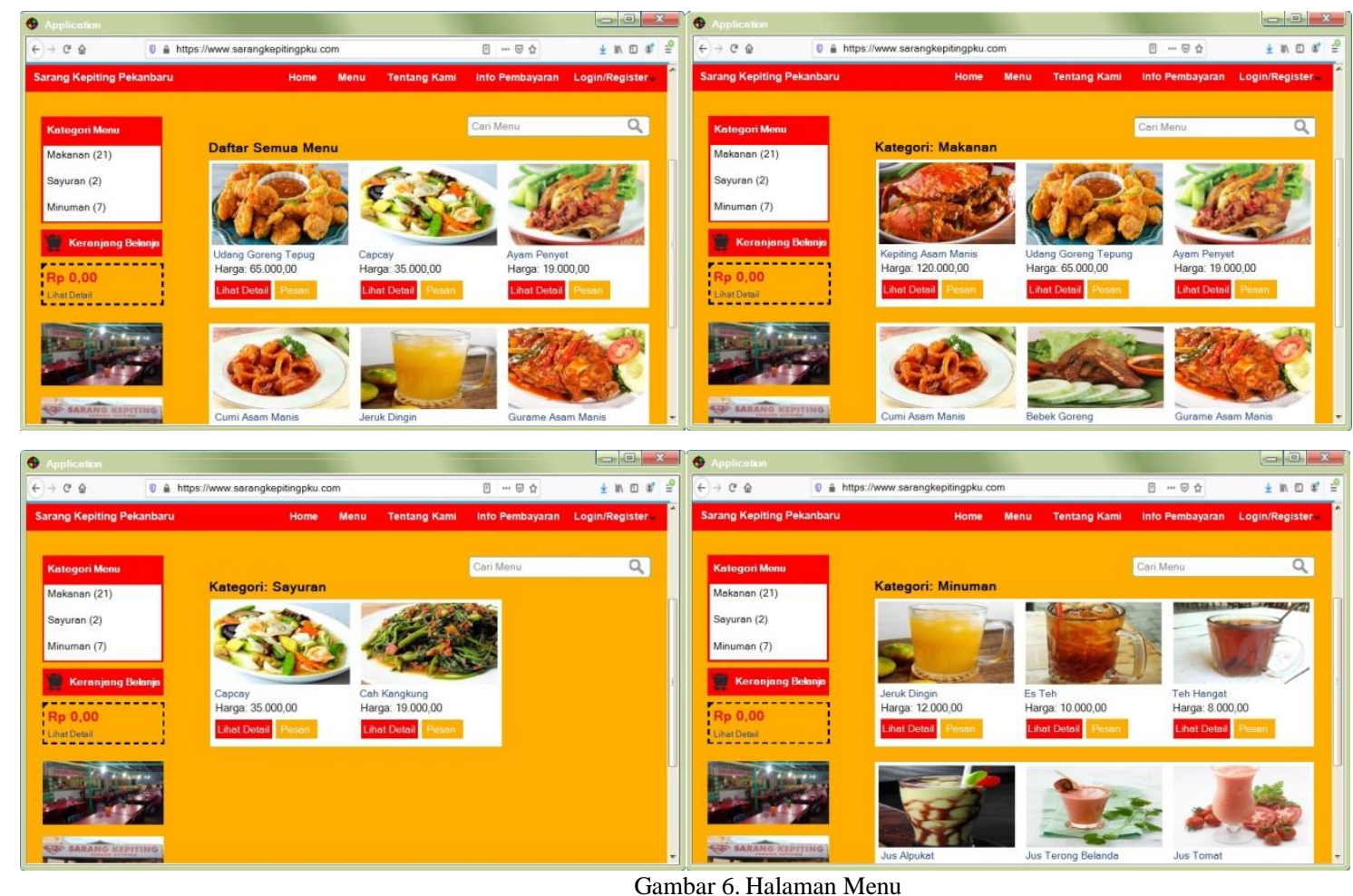

\subsection{Tampilan Halaman DetailMenu}

Halaman detailmenu menampilkan foto, harga dan status ketersediaan menu yang dipilih oleh pengguna. Tampilan halaman ini juga disertai tombol pesan yang dapat diklik oleh pengguna apabila ingin melakukan pembelian.Adapun tampilan dari halaman detailmenu dapat dilihat pada Gambar 7.

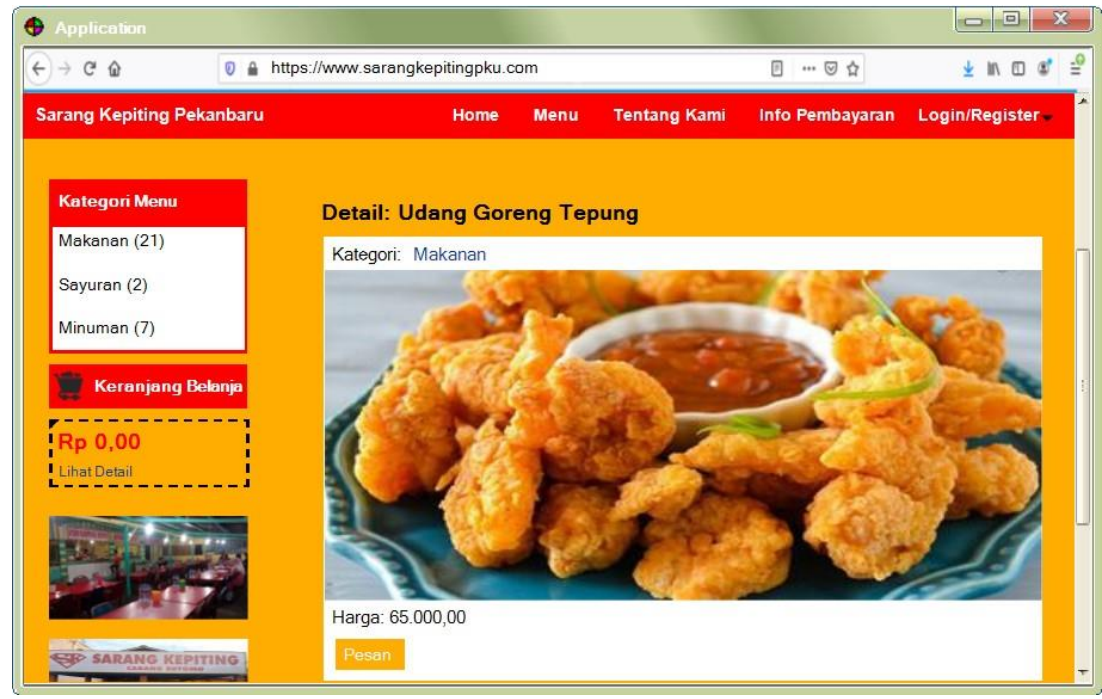

Gambar 7. Halaman Detail Menu

\subsection{Tampilan Halaman Keranjang Anda}

Halaman keranjang anda berfungsi untuk menampilkan menu yang telah dipesan pada halaman detail menu beserta total harga yang harus dibayar oleh pengguna. Untuk menampilkan menu keranjang anda, pelanggan dapat meng-klik tombol keranjang belanja yang berada pada bagian kiri halaman web.Apabila pengguna telah memesan menu-menu yang diinginkan, maka pengguna dapat meng-klik tombol selesai belanja untuk melakukan pembelian.Pada halaman ini pengguna juga dapat mengedit pesanan seperti menambah kuantitas pesanan atau menghapus pesanan.Adapun tampilan halaman keranjang anda dapat dilihat pada Gambar 8. 


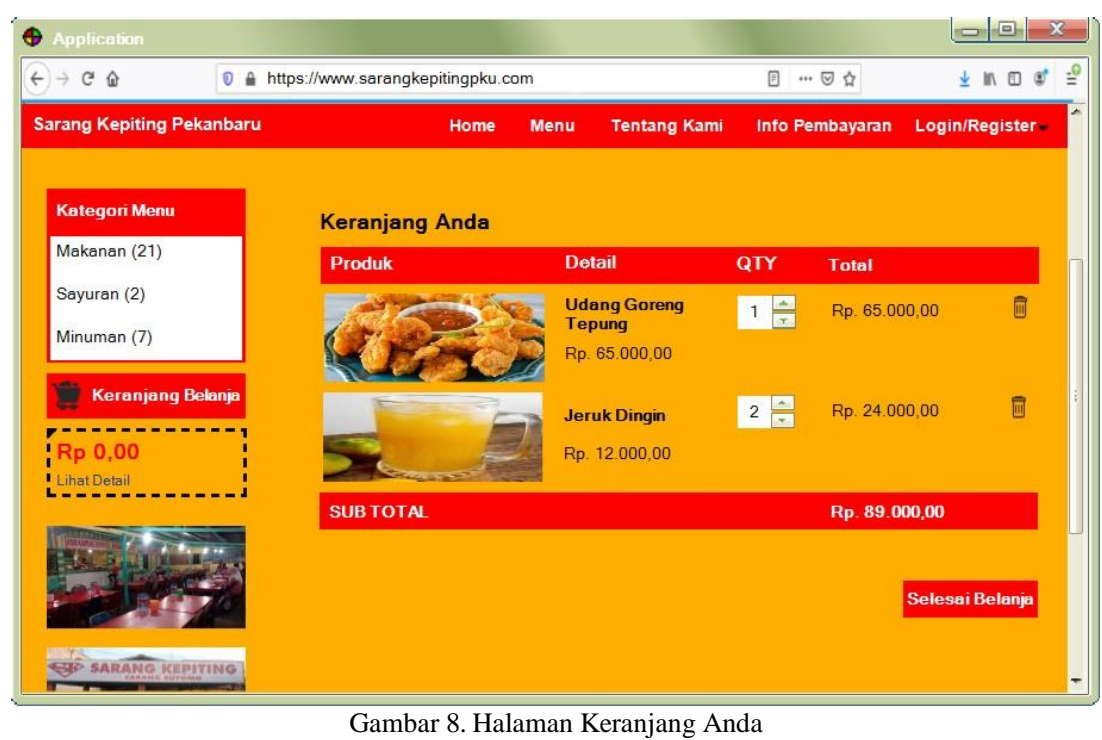

\subsection{Tampilan Halaman Detail Pesanan}

Dengan meng-klik tombol selesai belanja pada halaman keranjang anda maka pengguna telah melakukan pembelian ke Sarang Kepiting dan sistem akan menampilkan halaman detail pesanan yang dibeli. Halaman ini memberikan informasi mengenai nama produk yang dipesan, kuantitas produk yang dipesan dan total harga yang harus dibayar oleh pengguna. Adapun halaman detail pesanan dapat dilihat pada Gambar 9.

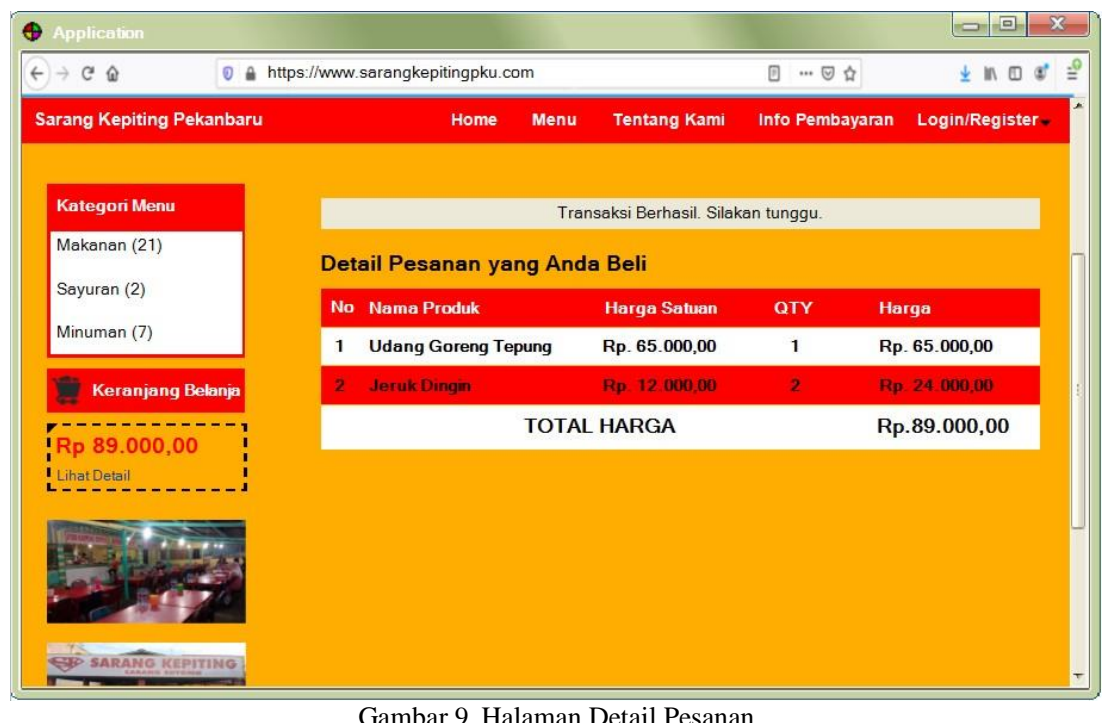

\subsection{Tampilan Halaman Info Pembayaran}

Halaman info pembayaran memuat informasi tentang bagaimana pengguna dapat melakukan pembayaran.Info pembayaran dapat diakses dengan meng-klik logo masing-masing metode pembayaran yang tersedia di Rumah Makan Sarang Kepiting. Dengan mengklik salah satu metode pembayaran tersebut maka pengguna akan mendapatkan info tentang cara pembayaran sekaligus melakukan transaksi pembayaran atas produk atau menu yang telah dipesan. Berikut adalah tampilan halaman info pembayaran yang dapat dilihat pada Gambar 10 . 


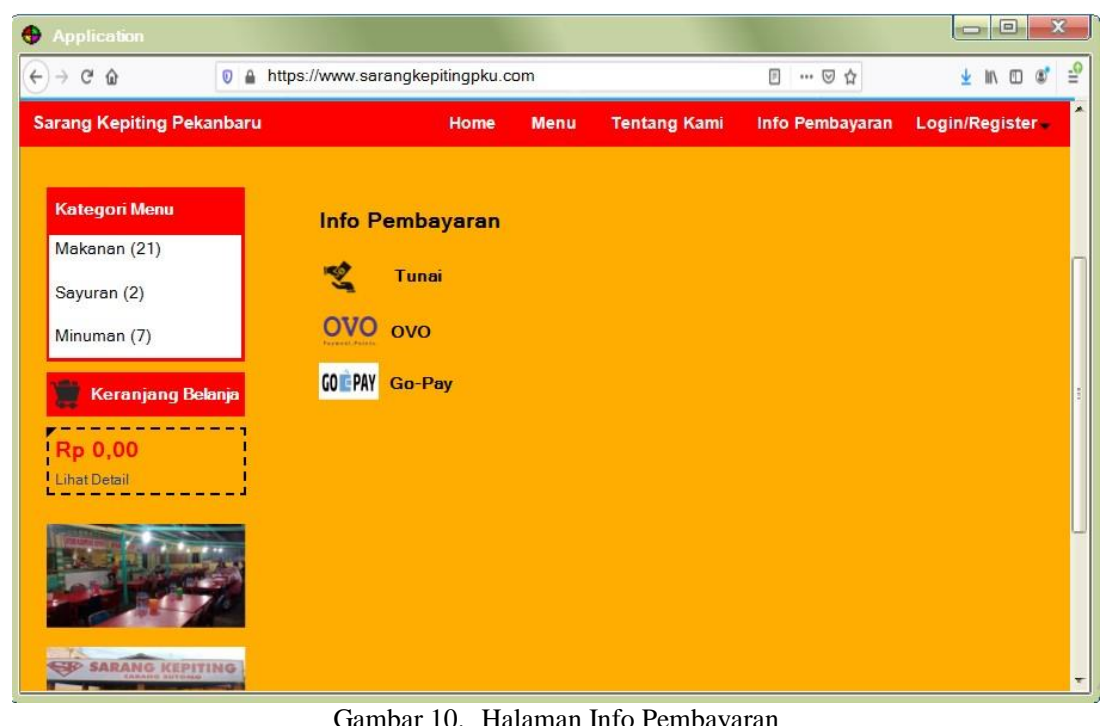

Gambar 10. Halaman Info Pembayaran

\subsection{Tampilan Halaman Tentang Kami}

Halaman tentang kami memuat informasi mengenai Rumah Makan Sarang Kepiting yang terdiri dari lokasi outlet dan kontak yang dapat dihubungi oleh pengguna.Adapun tampilan halaman tentang kami dapat dilihat pada Gambar 11.

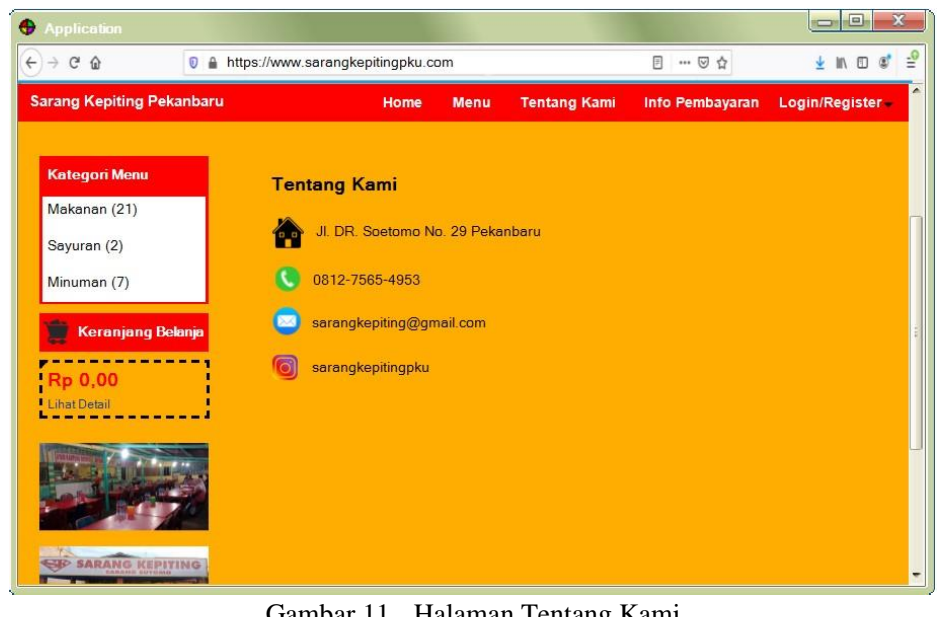

\subsection{Tampilan Logout}

Setelah transaksi berhasil maka pengguna dapat keluar dari sistem dengan meng-klik menu dropdown untuk logout.Adapun tampilan menu logout dapat dilhat pada Gambar 12.

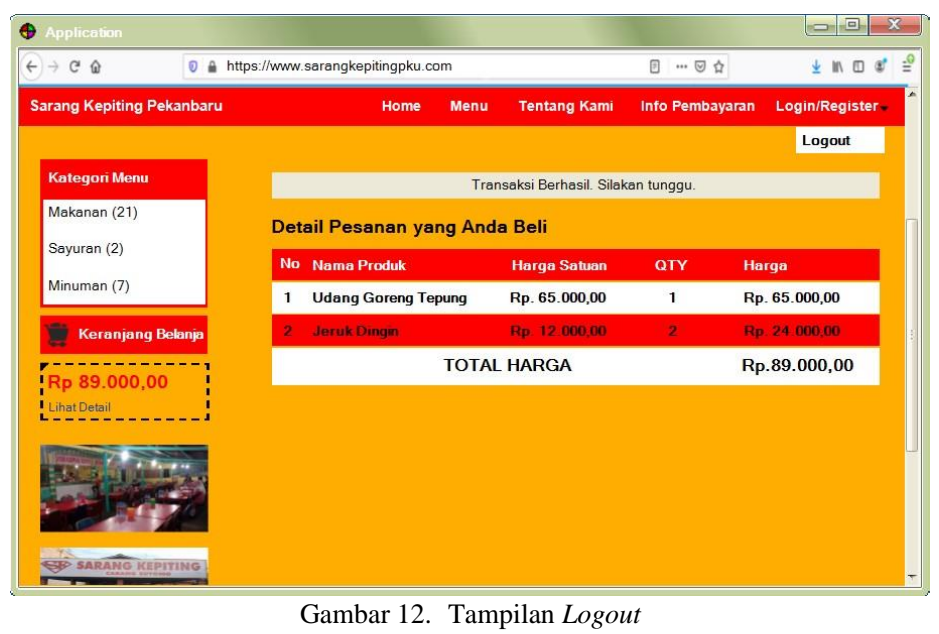




\section{KESIMPULAN}

User Interface pada penelitian ini dirancang menggunakan pendekatan User Centered Design (UCD) dengan 4 tahap penyelesaian yang terdiri dari analisis kebutuhan, perancangan, evaluasi dan implementasi. Berdasarkan hasil penelitian dapat disimpulkan bahwa penerapan User Centered Design (UCD) pada perancangan User Interface dapat memberikan hasil yang lebih baik dengan menitikberatkan pada kebutuhan pengguna sehingga memungkinkan User Interface yang dihasilkan tidak hanya mudah untuk digunakan (user friendly) tetapi juga dapat menarik minat pengunjung untuk melakukan pembelian.

\section{DAFtar Pustaka}

[1] H. Joo, "A study on understanding of UI and UX, and understanding of design according to user interface change," International Journal of Applied Engineering Reasearch, vol. 12, no. 20, pp. 9931-9935, 2017.

[2] A. Tarute, S. Nikou, and R. Gatautis, "Mobile application driven consumer engagement," Telemat Informatics, vol. 34, no. 4, pp. 145-156, 2017.

[3] A. Krisnoanto, A. H. Brata, dan M. T. Ananta, "Penerapan metode user centered design pada aplikasi e-learning berbasis android (studi kasus: SMAN 3 Sidoarjo,” Jurnal Pengembangan Teknologi Informasi dan Ilmu Komputer, vol. 2, no. 12, hal. 6495-6501, 2018.

[4] I. Sommerville, Software Engineering 9th Edition, Boston: Addison-Wesley, 2007.

[5] B. Shneiderman dan C. Plaisant, Designing the User Interface: Strategis for Effective Human-Computer Interaction5th Edition, Bangalore: Pearson Education, 2010.

[6] S. Fauzia, F. E. M. Agustin, U. Syaripudin, dan Y. Ichsani, "Perancangan prototype tampilan antarmuka pengguna aplikasi web kamardagang.com dengan teknik flat design pada PT. Selaras Utama Internasional,” Jurnal Teknik Informatika, vol. 9, no. 2, hal. 148-157, 2016.

[7] L. Fanani, M. T. Ananta, K. C. Brata, "Penerapan user-centered design dalam pengembangan aplikasi pencarian gedung berbasis android," CYBERNETICS, vol. 2, no. 02, hal. 225-233, 2018.

[8] M. N. E. Ghiffary, T. D. Susanto, dan A. Herdiyanti, “Analisis komponen desain layout, warna dan control pada antarmuka pengguna aplikasi mobile berdasarkan kemudahan penggunaan (studi kasus: aplikasi olride)," Jurnal Teknik ITS, vol. 7, no. 1, hal. A143-A148, 2018.

[9] R. C. N. Santi dan A. Fitriyah, "Perancangan interaksi pengguna (user interface design) menggunakan metode prototyping," Jurnal Teknik Informatika, vol. 9, no. 2, hal. 108-113, 2016.

[10] G. I. Marthasari, D. Risqiwati, dan T. B. T. Dewi, "Rancang bangun dan implementasi website e-commerce UKM GS4 Malang menggunakan metode prototyping," Seminar Nasional Teknologi dan Rekayasa (SENTRA), hal. V-1 - V-10, 2017.

[11] I. S. Y. Saputri, M. Fadhli, dan I. Surya, "Penerapan metode UCD (User Centered Design)pada e-commerceputri intan shop berbaasis web," Jurnal Nasional Teknologi dan Sistem Informasi, vol. 03, no. 02, hal. 269-278, 2017. 